\title{
AFRIKANER REFORMED \\ MISSIONARY ENTHUSIASTS AND \\ THE VOORTREKKERS: WITH SPECIAL \\ REFERENCE TO DINGAANSDAG/ \\ GELOFTEDAG AND ALSO THE 1938 \\ EEUFEES *
}

\section{Retief Müller}

University of Stellenbosch

retiefmuller@sun.ac.za

\section{ABSTRACT}

The missionary discourse in Afrikaner Reformed Christianity has been controversial, because it is implicated in the development of early apartheid policies, which were subsequently implemented by National Party governments. This article does not directly concern itself with apartheid, however, but rather with the ideological backdrop against which this policy developed, i.e. Afrikaner nationalism. Afrikaner nationalism was deeply informed by a mythological reconstruction of the Voortrekkers as ideal Afrikaners. For this reason, the 1938 ox-wagon centenary Trek was a formative occasion in Afrikaner, and

* This article originates from a paper read at the CHSSA conference at North West University, Potchefstroom, August 2015.

\section{UNISA $\cong$}

Studia Historiae Ecclesiasticae Volume 41 | Number 3 | 2015 pp. $111-130$
DOI: http://dx.doi.org/10.17159/2412-4265/2015/445 Print ISSN 1017-0499 | Online 2412-4265 (C) 2015. Studia Historiae Ecclesiasticae 
consequently South African history. What role did the Afrikaner missionary/ evangelical discourse play within these celebrations and within commemorations of the Voortrekkers and Geloftedag more generally? With a particular focus on the early to middle twentieth century, this article demonstrates that missionary and evangelical co-optation of this discourse was indeed pronounced, at the centre of the political situation, but also containing an element of surprise and the potential for unexpected outcomes in at least a couple of cases.

Keywords: Afrikaner; Voortrekkers; nationalism; apartheid; Reformed missionary discourse; Dingaansdag; Geloftefees; 1938 Eeufees

\section{INTRODUCTION}

In speaking of commemoration we are skating on thin ice. One runs the risk of confusion, of placing one's own convictions on a slippery slope to possible deconstruction and even ridicule. Yet speak of it we must, because trapped between the desire to forget painful themes from the past and the need to remember where we came from, our memories, or rather the memories of our ancestors haunt our private and public discourse. Memory is a slippery thing, particularly when occurring in a dreamlike state, as everyone knows. As South Africans from diverse backgrounds, we find that memories, including communal memories, create different sentiments: shame for some, pride for others; shameful pride for yet others; and perhaps even a good measure of prideful shame for some. Communal memory and commemoration might, however, be employed as political acts par excellence. That was certainly the case in the early twentieth century creation of Afrikaner nationalism in South Africa. Monuments, the visual signs of acts of commemoration, have been in the spotlight recently in South Africa, and so it is appropriate to reflect on and interrogate this theme.

\section{REMEMBERING/COMMEMORATING THE DRC MISSIONARY TRADITION?}

My own research in the recent past has focused on certain aspects of the Afrikaner missionary tradition. Although I find it an extremely interesting topic for different reasons, I am also a little uncomfortable with it for other reasons. One is that some of my own deceased relatives were involved in this tradition, and so when I speak of a haunting ${ }^{1}$ of the ancestors, I do mean it quite literally. Secondly, there are familiar issues such as the connection between mission and colonialism, imperialism, cultural

1 I should perhaps also acknowledge that a 'haunting' does not have to be interpreted negatively. Viewed positively we refer to it as a vision or an inspiration. 
chauvinism, and particular to the Afrikaner case, mission's connection with policies of apartheid.

So is this a tradition to commemorate? Perhaps not, even if one is open to the possibility that individual people who participated in this tradition actually acted against the exclusivist trends within their social/cultural mainstream. Nevertheless, it certainly is a tradition to remember, to criticise, to deconstruct, I would like to argue. However, does an act of conscious remembering (or should we say re-awakening, because this concerns a disturbance of the souls of the dead, rather than a real case of remembrance) such as entailed in the research on a specific tradition, not actually constitute a kind of sophisticated scholarly commemoration? I am not entirely sure this question should be answered and dispensed with all too quickly. In as much as hagiographic tendencies are easily identified and duly disparaged when identified in the works of others, we all have our blind spots, and perhaps I am also not immune to this type of indulgence.

Archival research, apart from having the characteristic of being monotonous and hence instilling the quality of humility into anyone wishing to mine for gold in often vaguely charted vaults, also has a tendency to spring surprises. In asking about missionary connections to Voortrekker commemorations I have been quite surprised to learn an interesting fact about a certain nineteenth century Rev. Huet.

\section{REV. DAMMES PIERRE MARIE HUET: DEFEATING A SINGLE STORY OF THE PAST}

Rev. D.P.M. Huet is best known in South African church history for his strong and clear opposition to the 1857 decision by the synod of the DRC to allow segregation of congregations along racial lines. In a 1975 essay, Wolfram Kistner describes the treatise 'Eéne Kudde en éen Herder' as a 'passionate protest' against the synodical decision, as well as the background context of white colonists who tended to see themselves as Christian by virtue of their skin colour and European heritage, which they contrasted with blacks as uniformly heathen in spite of their actual religious affiliation. Huet is quoted as follows: "[W]e have to contradict a heresy out of which many wrong sentiments flow forth. We refer to the fact that people use the term "heathens" and "non-whites" as having one and the same meaning... The word "heathen" refers to the religious state and not to colour.'"

In this treatise, Huet explicitly rejects the later nationalist dogma (see J.G. Stydom 1938 for example) that 'Africans are a special nation and that separate churches should be established for them'. ${ }^{3}$

2 D.P.M. Huet, 'Eene Kudde en een Herder' quoted in W. Kistner, 'The 16th of December in the context if Nationalistic thinking,' in Theo Sundermeier (ed.) Church and Nationalism in South Africa (Johannesburg: Ravan Press, 1975), 77.

3

Kistner 1975, 77. 
Contrary to this idea, Huet held firmly to a minority opinion within his time and context as a white Afrikaner man in the middle of the nineteenth century. Huet affirmed Christian unity, de-emphasised language and ethnicity, and argued that the Christian church becomes a nation in its own right, superseding other divisions.

It is worth bearing in mind that Andrew Murray Sr. presided over these 1857 synodical proceedings, and one of his sons (William) introduced the contentious motion. This well-known evangelical and missionary-oriented family apparently proposed this measure in the hope of negating the effects of what they perceived as the 'weakness of some', specifically in order to protect mission-related sentiments within the DRC. ${ }^{4}$ Andrew Sr. is, however, also on record for decrying the racial discrimination practised by some of his church members. The Cape DRC, of which he was the moderator, furthermore opposed the Great Trek. ${ }^{5}$

A further twist in the tale involving Rev. Huet, is that this clergyman from Natal is also notable for being influenced by the religious revival that swept through Christian communities in the late nineteenth century, and in which Andrew Murray Jr. had played a major role. Huet was himself an ardent mission enthusiast, ${ }^{6}$ but obviously one who had come to different conclusions regarding the implementation of mission than what was increasingly the majority opinion, i.e. alongside a policy of racial segregation.

Huet's geographical context among the Voortrekker communities of Natal, however, influenced his thinking in a different way in the sense that he became the first significant clerical proponent of commemorating Geloftedag as a religious celebration within the DRC in 1864 . This might seem strange for someone who was clearly not nationalist in terms of his religious thinking, yet as Kistner (1975) subtly suggests, one has to take care to not read our own sentiments regarding what this day entailed back into the scenario confronted by Huet. Kistner insists convincingly that there was nothing nationalist in Huet's proposal, as he simultaneously proposed the institution of English language services in the DRC in Natal. Apparently he had become worried that his church might be endangered by intermarriages between English and Afrikaans colonists with the latter steadily Anglicising in the process. The Blood River commemoration would then serve as a reminder of what he evidently believed to be the miraculous intervention of God in history when called upon, and hence as a magnet for engendering some vitality into the DRC. As Kistner puts it: 'The deliverance of the Voortrekkers in a state of extreme emergency appears to have been the event which he wanted to have commemorated on December 16.' ${ }^{7}$ However, Kistner is adamant that given the views expressed in his abovementioned

4 Richard Elphick, The Equality of Believers: Protestant Missionaries and the Racial Politics of South Africa (Charlottesville [Va.]: University of Virginia Press, 2012), 44.

5 Elphick 2012, 46.

6 See Kistner 1975, 76ff.

7 Ibid, 77. 
treatise, nationalism remained absent, and that "he cannot have understood the battle of Blood River as a victory of Christianity over heathenism' ${ }^{8}$ Perhaps this is a valid conclusion, or on the other hand, perhaps Kistner was relying too much on a preconceived definition of what constituted nationalism to be able to harmonise this apparent anomaly in the thinking of Rev. Huet.

Whatever the case may be, the remembrance of someone like Huet in all his complexity defeats binary narratives of early developments in Afrikaner national ideology. Let me now consider a more straightforward example of a missionary's involvement with Geloftedag. I refer to the case of J.J. Ross, who was a pioneer missionary of the DRC at Witzieshoek, on the border of Lesotho and the northeastern Free State, in the late nineteenth to early twentieth centuries.

\section{'EERW.' J.J. ROSS, HIS BACKGROUND AND GELOFTEDAG SERMONS}

Ross has an interesting story as recounted in his book, ${ }^{9}$ which is a kind of memoire that he presents as a historiography of the Witzieshoek mission. Ross had some tough experiences as a missionary among the Basotho people, particularly as a result of turmoil caused by the Anglo Boer War. Although he could write with pride that the mission never missed a Sunday service during the war, the fact of the matter is that after the war the Basotho seemed to turn against the DRC mission, and moreover against him personally. They then favoured everything English and no longer wanted anything to do with the losing Boers and their church. A Basotho desire to be associated with the winning side was at any rate how Ross interpreted the post-war antagonism he experienced. Some of the indigenous leaders even went as far as to petition the imperial authority to have him removed from Witzieshoek, but without success. His writing on these proceedings is not entirely devoid of bitterness.

However, in 1917 Rev. Ross delivered four sermons at the 'Dingaansfeest' that was held in Newcastle, Natal, 15-16 December. ${ }^{10}$ They are remarkable documentation for my purposes, because they speak directly to my interests: a missionary preaching on the commemoration of Geloftedag. Not any Geloftedag at that, but during the period of the First World War when Afrikaner nationalism was already on the rise as evidenced by the abortive yet much sentimentalised Rebellie that had occurred a couple of years earlier.

It is notable in a way that Ross does not make mention of this war that involved many South Africans, but of course since their participation tended to be unpopular

\footnotetext{
8 Ibid.

9 J. J. Ross, Die Sending te Witzieshoek, Paulus Mopeli, en andere sake rakende die sending aldaar (Bloemfontein: Nasionale Pers, 1930).

10 Vier Preken geleverd door eerw. J. J. Ross te Doornpoort, New Castle, Natal, met Dingaansfeest, 15-16 Des. 1917. (Stellenbosch: Pro Ecclesia, 1918) DRC archive, B2139.
} 
with Afrikaners, this is also not really unexpected. What is more interesting is that one could read through all of these lengthy sermons without at any stage getting an inkling that Ross had been a missionary, had one not known the name and title of the author. He does not reference himself in any way, nor does he address the theme of mission. One might have expected some connection, but here the reader is disappointed. The Voortrekkers are compared to the biblical Israel in the introductory sermon and especially in their absolute dependence on God in their different pilgrimages through areas of wilderness.

A lot of what he describes is fairly typical, but then he makes a point that seems to warn against nationalistic enthusiasm. He argues that the honour for the Voortrekkers' glorious history should go to God:

Dingaansdag moet niet ontaarden tot een volksverheerliking. Daardoor zou de dag met eens zijn betekenis verliezen en God zou onteerd worden...Dingaansdag moet niet wezen een volksverheerliking maar een Godsverheerliking. Laat ons als een volk daaraan denken, en waken tegen alle afwijking daarvan. ${ }^{11}$

It seems ironic with the benefit of hindsight that this type of warning should be issued in the midst of an event so highly conducive to and indeed frequently used for exactly the kinds of sentiments he warns against. Ross nevertheless does not shirk from identifying Dingaan with 'a personification of what had to be destroyed'. His was a 'cruel, destructive, and God mocking' ${ }^{12}$ heathendom. Ross implies the notion of Voortrekkers as guardians when he states that many smaller, weaker tribes were being persecuted by the Zulus, and those were effectively saved by the action of the Voortrekkers against Dingaan. Hence the Voortrekkers acted as saviours of Africans not associated with Dingaan. Although Ross does not use the term, I think this certainly implies the idea of voogdyskap.

Historians have often pointed to the similarities or correspondences between developments in the American South and South Africa, particularly in reference to the identity formation of the white Southerner and the Afrikaner. I therefore found it interesting that Ross in one of his sermons referred to the American Civil War, but then in close identification with Abraham Lincoln and the Northerners by implication, rather than the perhaps more obvious South. Ross refers to an anecdote told to him by an American pastor of a time during the war when the Union armies found themselves in dire straits. ${ }^{13}$ One evening Lincoln then apparently showed up at the door of the famous New York preacher, Henry Ward Beecher. Together the two prayed throughout the night. The next morning Lincoln returned to his command

11 'Dingaan's day should not degenerate into a volk's glorification. As such the day would lose its meaning and God would be dishonoured... Dingaan's day should not be a volk's glorification, but God's glorification. Let us remember that as a volk, and guard against all deviation thereof [my transl.]. Ibid, 4.

12 Ibid, 6.

13 Ibid, 11f. 
post to find the tide of the war starting to turn in his favour. This story is told in commentary on the biblical passage describing Jacob's battle with the Angel of God. The understanding is that Lincoln and Ward's night of prayer was similarly a spiritual battle with the Lord; no easy thing.

Ross does not draw a direct parallel with Sarel Cilliers's and Andries Pretorius's vow preceding Blood River, but the metaphor is obvious enough. Instead he brings it home to his contemporary listeners, individualising and spiritualising the idea of intense prayer as a struggle with the Lord. He suggests that Jacob had to go through his Pniel, Jesus through his Getshemane, the Voortrekkers their own Weenens and Blaaukrantz, through which they all struggled in prayer, but Blood River was the outcome; a victory such as the Union army victory over the Southern rebels. Elsewhere in a sermon on the biblical Elisha, Ross states that the Voortrekkers' victory was won with the aid of heavenly beings, horses and chariots. ${ }^{14}$

It is noteworthy that all four sermons were based on Old Testament texts. Nowhere does Ross give explicit exegesis or commentary regarding his current context, except in a final paragraph termed 'Toepassing' [Application]. Elsewhere in the preaching when he speaks of contemporary enemies they remain unnamed. He states: 'Wij worden omringd door vijanden gevaarliker dan de barbaarse horden van Dingaan voor de Voortrekkers waren; omdat zij sich aan ons voordoen als vrienden en engelen des lichts.' ${ }^{15}$

In the Toepassing Ross mentions that this commemoration refers them back to the rise of a bright star, 'de ster van hoop en verlossing voor het Afrikaanse volk, n.1., de overwinning over Dingaan...' 16

Ross furthermore compares the Great Trek to the way young eagles grow into adulthood and learn to fly. It is a dangerous operation, occurring not without much faith, but by forcing the Voortrekkers to leave the relative comforts of the Cape Colony in search of a life of freedom elsewhere, God was actually acting like an eagle parent forcing the chicks out of the nest. Could anyone now blame the Afrikaner that they loved freedom? No. This is what God had prepared them for! ${ }^{17}$

Ross warns the Afrikaner against internal division, because uniformity was surely one of the lessons learned from Dingaansdag. ${ }^{18}$ Finally in good puritanical fashion, Ross laments the contemporary neglect of God's word, God's day, God's house. He berates the ignorance of the Afrikaners for not reading enough. And then:

14 Ibid, 22.

15 'We are being surrounded by enemies more dangerous than the barbarian hordes of Dingaan were for the Voortrekkers; because they are pretending to be friends and angels of the light' [my transl.] Ibid, 19.

16 'The star of hope and salvation for the Afrikaner volk, namely the victory over Dingaan' [my transl.] Ibid, 28.

17 Ibid, 29.

18 Ibid, 38. 
'Voorwaar een krachtige en diepgaande herleving is een absolute noodzakelikheid geworden!' 19

This reference to the evangelical idea of revival is one of the only places where the influence of Ross's missionary tradition might be seen. As for the rest of the sermons, the theme of mission remained wholly absent.

No doubt Ross was well aware of the general Voortrekker suspicions regarding missions and missionaries, and so this might have played a role in leaving out any reference to his life's work in these sermons. But this was 1917. Elsewhere, further along the path of history and Afrikaner nationalism, more sophisticated and daring reinterpretations had become possible.

In the Gedenkboek: Voortrekker Eeufees 1838-1938 the very same Ross contributed a chapter on the characteristics of the Voortrekkers, in which he implores his readers to remember whatever is 'good' in the Voortrekker tradition, of which he found many examples. Most provocatively and in contradistinction to his 1917 warning against honouring the nation, he now refers to the well-known Tertullian idea of the blood of the martyrs being the seed of the church, claiming that one could assume the blood and suffering of the Voortrekkers to be the seed of a 'great, free united Boerevolk'. I also mention the following sentences from his concluding paragraph which are indicative of his sentiments generally:

Eer die Voortrekkers deur te handhaaf wat hulle voor gelewe en gesterwe het. Beoefen hul godsdiens, volharding en rassesuiwerheid. Hul deugde moet nie alleen bewonder en aangeprys word nie, maar ook elke dag beoefen word. ${ }^{20}$

\section{EERW. M.W. THEUNISSEN AND THE GEESTELIKE EEUFEES MONUMENT}

During the time of the Voortrekker centenary celebrations in 1938, the volk was deeply conscious and perhaps rather impressionable regarding its own role in history. Mission interested dominees and church people seized on the spirited state of things to reinterpret the discourse in a way to open people's hearts and purses also for mission work.

A highly significant venture then was the founding of the 'Geestelike Eeufees Monument' (G.E.M) [Spiritual Centenary Festival Monument]. In an incompletely dated 1938 article for the pamphlet the 'Oorvloedige Lewe' the Transvaal DRC mission secretary, Johan Reyneke writes with evident pride of the great strides made in

19 'Truly, a powerful and deeply penetrating revival has become an absolute necessity' [my transl.] Ibid, 32 .

20 'Honour the Voortrekkers by maintaining what they had lived and died for. Practise their religion, persistence and racial purity. Their virtues should not only be admired and praised, but must be practised each day' [my transl.]. Gedenkboek: Voortrekker Eeufees 1838-1938, p. 83. 
terms of this fund intended for missionary work in Zululand. ${ }^{21} \mathrm{He}$ relates tales he had heard and letters received, all of which indicate a spiritual conviction overwhelming readers of the abovementioned tract to contribute out of situations of personal crisis and even temptation. It is noteworthy that all the letter writers mentioned by him were apparently women. One writer stated that she had been saving money to buy a Voortrekker skirt. After reading about the need of the G.E.M. she decided to rather donate the 10 shilling she had saved to this missionary cause. Another donated an engagement ring which she had worn for 18 years. Still another had been saving up for a refrigerator. Yet, against the opposition of friends and family members, which in the letter that Reyneke quotes from she describes along the lines of temptation from Satan, she donated all 42 pounds she had thus far saved to missionary and church activities, including 20 pound for the G.E.M.

The history and activities of the G.E.M. as well as mission work in Zululand, generally are detailed in the autobiography of Eerw. M.W. Theunissen, the pioneer DRC missionary supported by the G.E.M. fund. He states that when great sums of money were being collected for the Voortrekker Eeufees Monument, the idea emerged under the leadership of Rev. J.C.G. Kotzé to start this spiritual monument fund. Under his direction more than a 1000 pound was collected for the founding of the main mission station in Zululand. The idea, as Theunissen describes it, was to honour God by the collection of Zulu souls for Christ: 'vir Sy wonderlike verlossing uit die hand van die barbaar Dingaan en sy woeste heidense hordes. ${ }^{22}$ The phrase 'heathen hordes' or something similar in connection with Dingaan features rather often in diverse correspondence and Afrikaner writing that I have seen.

The G.E.M. main station and church were then constructed at Kwandunu, a site where two chiefs, Dinizulu and Sibebhu, had in a former era battled for the Zulu kingdom. Theunissen (1950) reports to have heard that after the battle, bodies littered the earth to the extent that one could not step anywhere and that the blood streamed like water underneath the bodies and down a ridge. ${ }^{23} \mathrm{~A}$ ghastly reminder then of Blood River, but on this occasion without any Voortrekker contribution to the bloodshed. Rather here the Voortrekker descendants, with Theunissen as first minister, would conceptualise themselves as heralds of salvation.

Theunissen spends a whole chapter on the foundation of the G.E.M. station, including the construction of the church, which apparently was meant to be a monument in the full sense. The missionary builder, a Mr Fourie, was proud of his work and insisted that everything he did should be to the honour of God. When

21 Vir die 'Oorvloedige Lewe'. Geestelike Eeufees Monument in Soeloeland. Deur Ds. Johan Reyneke, Sendingsekretaris, Posbus 433, Pretoria. DRC archive, Stellenbosch.

22 ...for his wonderful salvation from the hand of the barbarian Dingaan and his rough heathen hordes' [my transl.] M.W, Theunissen, Na die land van Dingaan (Stellenbosch: CSV Boekhandel, 1950), 104.

Ibid, 106. 
someone once commented on the beautiful 'Kaffir [sic] church' he was constructing, he answered: 'Excuse me, sir, I am not building a kaffir [sic] church, but a God house' 24 [my transl.]. One might perhaps write a whole article analysing the theological and anthropological context of this statement, but clearly Mr Fourie did not want anyone to think he was honouring black South Africans.

The whole construction process with the somewhat uncooperative aid of the Zulus, gave missionary Theunissen many headaches. He admits that it requires 'patience to attempt such an organisation with natives. The missionary sometimes had to act almost as crassly as Dingaan himself' ${ }^{25}$ [my transl.]. Ironically then, or perhaps appropriately, depending on your point of view, a subsequent venture of the Transvaal mission commission was the construction of a mission station at Dingaanstad in order to teach the Zulus not to commit 'acts of murder anymore'. Theunissen quotes here from a 1922 speech by Rev. A.J. Louw at the unveiling of Piet Retief's monument at the site where Dingaanstad was later constructed. Louw started with: 'Laat ons die naturel vorm...'26

The idea of forming or civilising the native was of course present in much missionary thinking, although not necessarily expressed in those terms. But this is certainly partly what is expressed by the term voogdyskap (trusteeship), which actually came more explicitly to the fore in an article of Theunissen in Die Kerkbode (1938). Here the missionary describes in glowing terms how the grateful descendants of the Voortrekkers were coming together to thank God for among other things, 'the survival of white civilisation and the triumph of Christendom over savagery' [my transl.]. And then, which I leave in the original Afrikaans:

As oorwinnaars wat hulself die reg van voogdyskap oor die oorwonnenes toegeëien het, en dit ook in werklikheid geword het, word van ons deur die ewige Meester 'n christelike voogdyskap verwag. Hierdie voogdyskap sal ons seker nie met meer waardigheid kan handhaaf as om aan die oorwonne Zoeloe-volk die Evangelie van die Christus te bring nie. ${ }^{27}$

Theunissen closes his argument with a plea for contributors to this mission work among the 'inboorlingvolk' that had the greatest role in the birth of the Afrikaner. He states that it is his personal wish that the mission station in Zululand should be a 'monument dedicated to God and that would testify to the Christian magnanimity of the descendants of the Voortrekkers'. ${ }^{28}$

24 Ibid, 110.

25 Ibid, 112.

26 'Let us form the native...' [my transl.] Ibid, 119.

27 'As victors who have claimed the right of trusteeship over those defeated, and who have in reality become such trustees, a Christian trusteeship is expected of us by our eternal Master' [my transl.] M.W. Theunissen, 'n Roepstem uit die land van Dingaan', Die Kerkbode, 14 Desember 1938, p. 28.

Ibid, 29. 


\section{THE BLOEMFONTEIN MISSION CONFERENCE OF 1938}

From 29 September to 3 October 1938, Bloemfontein hosted a mission conference for the four regional white DRCs in South Africa. This conference, apparently occurring only a few days before the ox-wagons of the centenary trek arrived, was called into being by the Cape Synod. G.B.A. Gerdener, a former mission secretary in the Cape and Johannes du Plessis's successor as professor of mission at the Stellenbosch Seminary, and editor of the missionary journal Op die Horison, played a leading role at this conference. ${ }^{29}$ The combined volume containing the papers given at the conference is notably titled ' $n$ Eeu van Sendingwerk' ['A Century of Mission Work'], perhaps in response to the title of the abovementioned brochure by Gerdener, but the point is obvious in both cases. The Voortrekkers' pilgrimage through the southern African interior was actually understood to be the start of a new wave of mission work.

Kerkbode articles before and after the conference drew the reading public's attention to various aspects of the conference, and not all in a positive light. One writer expressed disappointment that relatively few people attended, that the speeches were too long and not inspirational, etc. This article did, however, emphasise what was understood as some of the positive elements in the so-called new direction in mission where 'valuable' indigenous customs were left intact by the mission. This was supposedly good because it would be a strong argument in favour of segregation, allowing the 'native to develop and use his talents in his own environment...' ${ }^{30}$ [my transl.].

A preceding editorial piece a couple of weeks earlier held great expectations, however. The fact that this conference was to be held during the Voortrekker centenary was emphasised as a theme that would increase its worth and value. Mission work, when done right, is described as the most important solution to race questions. The assumption seems to be that blacks were uniformly heathen and the descendants of the Voortrekkers were Christian:

Die inboorling het die Voortrekker met die moordende assegaai tegemoet gegaan. Die nageslag van die Voortrekker het, as weerwraak, die inboorling die seën van die Evangelie gebring. Vir altwee seksies van die samelewing is dit van lewensbelang dat die deel wat die lig besit dit sal bring aan die deel wat nog in duisternis verkeer. ${ }^{31}$

29 G.B.A. Gerdener, 'n Eeu van Genade: 1838-1938'.

30 'Die Sendingkonferensie', Die Kerkbode, 9 November, 1938, p. 27.

31 'The native met the Voortrekker with the murderous assegai. The descendants of the Voortrekkers have, as revenge, brought the native the blessing of the gospel. For both sections of society it is of utmost importance that the portion that owns the light will bring it to the portion still living in darkness' [my transl.] 'Die Aanstaande Sending-konferensie', Die Kerkbode, 24 Augustus 1938, p. 323. 
In his reflection after the conference, Dr D.R. Snyman (1938) discussed the growing importance of mission within the boundaries of South Africa. Up until then the focus had been on the foreign fields, but this had been to the detriment of natives in South Africa, also in terms of their relationship with the DRC, which had its image stained in the eyes of the local native that now considered them with an amount of prejudice in the estimation of Snyman. ${ }^{32}$ Snyman recommended a 'third centenary festival fund' to collect money for this type of mission work. To him it was imminently reasonable that the Afrikaner should take charge of this situation, because:

Wie ken die inboorlinge hier beter as die Afrikaners? Het God nie die Afrikanervolk hier geplaas en as volk in stand gehou nie? Waar die inboorlinge kennis maak met ons sendingwerk, is hulle nie alleen daarvoor dankbaar nie, maar selfs entoesiasties daaroor. Hierdie "Jerusalem"-veld mag nie langer braak lê nie. ${ }^{33}$

In terms of the conference itself, the papers were divided into three sections focusing on the past, the present, and the future. I restrict my focus on what was said regarding the present, and even there I refer to only two papers, the ones by J.G. Strydom (1938) and J.A. Retief (1938). These two had a protracted and at times strongly-worded debate in the pages of the Kerkbode a couple of years after these events regarding the wisdom, or not, of ecumenical co-operation in the mission field. ${ }^{34}$ On the present occasion Retief spoke directly after Strydom, and there is no indication that they had any altercation, although their somewhat divergent views are already apparent. Strydom, who more than any other missionary policy maker might be regarded as responsible for the development of apartheid ideology, delivered, true to form, a paper on the race question in South Africa.

Strydom, like the abovementioned missionary Ross on an earlier occasion, referenced the U.S.A. as an example. But in Strydom's case it was the South that was held up as an example to emulate. Strydom argued that there were hardly any discontents among the blacks in the southern states where they supposedly lived happily in this American version of apartheid in a situation where they might safely excel within their own differentiated schools, lines of employment, etc. This happy state of affairs, happy at least in Strydom's imagination, was contrasted with the discontented northern black who had to live in a situation of hypocritical equality,

32 D.R. Snyman, 'Die Sendingkonferensie te Bloemfontein: 29 September tot 3 Oktober', Die Kerkbode, 19 Oktober 1938.

33 'Who knows the natives here better than the Afrikaner? Did God not place the Afrikaner volk here, and preserved them as a volk? Where the natives come to know our mission work, they are not only grateful for it, but even enthusiastic. This "Jesusalem"-field may no longer lie barren' [my transl.] Ibid, 694.

34 See R. Müller, 'War and "racial feeling" in the writings of an Afrikaner missionary' Studia Historiae Ecclesiasticae, 40, 2 (2014): 71-84. 
where blacks were not allowed into hotels, and where black teachers were not in reality allowed to teach white children. ${ }^{35}$

The Voortrekkers came directly into the frame when Strydom defended their legacy on racial issues against 'liberal' detractors who portrayed them unfairly as oppressors of the black and coloured populations. Strydom, apparently taking it upon himself to speak on behalf of Afrikaners in general, stated that they, on the other hand, saw the hand of God in the Great Trek. The Voortrekkers were Calvinistic or Bible Christians, who were being led by the Word and Spirit of God, not by human drives. 'Daarom sit ons vandag hier, na ' $\mathrm{n}$ eeu, en ons is nog suiwer blankes en het nog suiwer Bybel-Christen-beskouwings oor hierdie en ander sake en gaan nog voort in die lig van die Christendom te versprei. ${ }^{36}$

Strydom delivered a lengthy apologetic for apartheid and the role of DRC mission to apply it in what he considered fairness and justice. Regarding the questions and comments noted after the address it is evident that not all agreed with Strydom's views, but it is furthermore obvious that the idea of apartheid as a comprehensive policy was still quite unfamiliar to many of the listeners, who needed clarification and explanation on some of the points he raised.

J.A. Retief from 'Mkhoma', Nyasaland delivered a paper on the 'world horizon'. The growing ideological divide between local mission policy makers and local missionaries on the one hand, and foreign missionaries on the other hand, is somewhat reflected in the sense that Retief (1938) mentioned nothing directly about apartheid or the South African context, but instead gave quotes and examples from ecumenical church bodies. He even gave a favourable mention of an unnamed famous Indian (probably Ghandi) who declared himself interested in the teachings of Jesus, but found himself dismayed by the actual state of churches in European countries. ${ }^{37}$

Rev. Retief did mention voogdyskap (trusteeship) in his introduction. Obviously sensing the need to link his speech to the ox-wagon and centenary celebrations, he stated that he had heard somebody mention during the recent festivities at Graaff Reinet that Blood River was the key to the voogdyskap of the natives given in the hand of Andries Pretorius and through him to 'us and our church'. The missionary did not elaborate, neither stating whether he agreed or disagreed with this statement. One might perhaps assume he accepted it uncritically. Then he proceeded to briefly mention the clouds of warfare on the world horizon, but beyond that he foresaw the bright rays of the sun of righteousness. From here on further his entire speech concerned challenges and opportunities encountered in terms of communicating the

35 J.G. Strydom, 'Die Rassevraagstuk in Suid-Afrika' in 'n Eeu van Sendingwerk., 52-53.

36 'That is why we are sitting here, after a century, and we are still pure whites and we have pure Bible-christian-views regarding these and other issues and are still continuing in the light of spreading Christendom.' Ibid, 57.

37 J.A. Retief, 'Op die Wêreldhorison', 'n Eeu van Sendingwerk, 75 
gospel in Nyasaland and elsewhere. At one stage he even briefly warned against 'unhealthy nationalism' as found in Germany, which was anti-mission according to Retief. ${ }^{38}$ The tone of this address was similar in a sense to that of another foreign missionary, A.A. Louw from Morgenstêr, whose speech was entirely about the blessings accrued through their work in Mashonaland. ${ }^{39}$ It is almost as if these foreign missionaries who were used to rub shoulders with representatives of other churches' mission bodies, including at world missionary conferences, were speaking a different language compared to their South African compatriots whose concerns were steadily turning political and increasingly nationalistic.

Speaking of nationalism then, I should mention a 1938 Geloftedag address at Blood River by D.F. Malan, who would institute apartheid as government policy when he became prime minister a decade later.

\section{D.F. MALAN, A 'LIBERAL' MISSION ENTHUSIAST WITH EXTREME NATIONAL VIEWS}

Theologian Vincent Brümmer published an important article in 2013 in which he discussed a paper delivered by Malan in 1910 at a church conference in Montagu. At this time Malan was still a conventional DRC minister, and his political career lay many years in the future. Brümmer found that Malan here expressed similarly progressive views on higher criticism to those which led to the termination of Johannes du Plessis's professorial career 20 years later. ${ }^{40}$ Another similarity to Du Plessis is the fact that Malan came from the evangelical wing in the DRC, and was an ardent mission enthusiast during his pastoral career in the DRC. Furthermore, and here in contradistinction to the anti-nationalistic Du Plessis, Malan already considered himself an Afrikaner nationalist as early as 1903, as pointed out by Richard Elphick. ${ }^{41}$

By 1938 Malan's political star was of course on the rise, and his address at Blood River minced no words about what he referred to as the new 'Groot Trek.' This new trek concerned Afrikaner people taking possession of the city similar to how in that earlier trek they invaded the northern wilderness. Their ultimate victory over their enemies in the city would be just as crucial for their future survival as a nation, and for the future of South Africa as a 'white man's' country as that earlier trek. ${ }^{42}$ Malan here envisioned the future and futuristically projected his audience

38 Ibid, 70.

39 A.A. Louw, Sr., 'Vrug op ons Sendingwerk', 'n Eeu van Sendingwerk, 131-139.

40 Vincent Brümmer, 'DF Malan en die Hoër Kritiek : algemeen,' Nederduitse Gereformeerde Teologiese Tydskrif 54, no. 3\&4 (2013): 130-42.

41 Richard Elphick, The Equality of Believers: Protestant Missionaries and the Racial Politics of South Africa (Charlottesville [Va.]: University of Virginia Press, 2012), 135-136.

42 Die Nuwe Groot Trek: Suid-Afrika se Noodroep. Dr. D.F. Malan se Rede op Bloedrivier, 16 Desember 1938 (DRC Church Archive). 
to a distant 2038, asking two self-evidently crucial questions: 'will there still be a poor white question....and will South Africa still be a white man's country?"43 [my transl.]. Malan, of course not aware of the fact that his second question could already be answered negatively in his own time for different reasons, nonetheless proceeded to paint a dark picture regarding the battle ahead that might insure the types of outcomes he was hoping for. The Afrikaner was in for a real battle, a real Blood River all over again: 'Die stryd met wapens is verby. Dit was die Voortrekkers $s$ 'n. Maar die nog heftiger, dodeliker stryd as wat hul s'n was, word nou beslis. Die slagveld is verskuiwe. U Bloedrivier is nie hier nie. U Bloedrivier lê in die stad .'44

Malan, who also described this trek to the city as the 'nuwe Groter Trek', contrasted it with the original trek, by positing that whereas the earlier one was from the centre of civilisation to the peripheral wilderness, this new trek was in a sense going back to civilisation. Malan depicted this as a great homecoming, which included returning emigrants from Angola and Argentina. This movement should convince all and sundry that this land where 'the Voortrekker's blood lies is your land, and the volk whose struggle and faith helped to shape us, is your volk. You have no other. With the Afrikanerdom you have to live and with the Afrikanerdom you have to die ${ }^{45}$ [my transl.].

Malan asked rhetorically whether this new trek was not going to lead to Afrikaner independence to an even greater extent than the founding of the Boer republics which were the results of the original Trek. He answered that, yes indeed, it may be so, but only if the 'Blood River today can be determined in exactly the same way as the Blood River of Andries Pretorius and Sarel Cilliers' ${ }^{46}$ [my transl.].

So who exactly were the enemies? Well no new revelations here, I think. They were the black, coloured and Asian population groups who were also moving into the cities at a quicker pace than the generic white. ${ }^{47}$ It is important to quote Malan directly here: 'As u oë het om te sien, u wat gekom het om Andries Pretorius en Sarel Cilliers te eer, staan dan vandag in u eie blanke laer by u eie Bloedrivier, en sien hoe die donker massas op u ingeslote blanke ras saamtrek. ${ }^{48}$

Malan sent a dire warning regarding educational opportunities in the city. $\mathrm{He}$ argued that if such opportunities were great for whites, then they were so much greater for non-whites, who had a greater distance to climb. Such opportunities

43 Ibid, 5.

44 'The battle with weapons is over. That was the Voortrekker's. But the yet fiercer, deadlier battle than theirs is now being determined. The field of battle has moved. Your Blood River is not here. Your Blood River is in the city' [my transl.] Ibid.

Ibid.

46 Ibid,7.

47 Ibid, 7.

48 'If you have eyes to see, you who came to honour Andries Pretorius and Sarel Cilliers, then stand today at your own white laager, at your own Blood River, and see how the dark masses are closing in on your beleaguered white race' [my transl.] Ibid, 8 . 
offered in the city then of course actually became a threat to the Afrikaners, because the educational distance was likely to decrease under the conditions as they were. 'Kennis is mag. Die strydkanse verander, maar ten koste van die blanke.' ${ }^{49}$

Malan then launched into a bit of an apologetic regarding the vulnerability of the Afrikaner in the city, who according to him had the heaviest burden to carry on the weakest shoulders. This is not to suggest of course that the Afrikaner had some sort of inherent weakness. To the contrary: 'Scientific research has determined that even under adverse conditions one third of its number count their intelligence above the average level of the white population' [my transl.]. ${ }^{50}$

However, and here the narrative shifts to exclude and 'other' the non-white population even to a greater extent than before, Malan argued in reference to the Carnegie report that the Afrikaner was particularly poor. 'Poverty, this I say in connection with the Afrikaner trekker, in connection with the child and inheritor of Blood River's heroic generation, and in connection with the struggle to keep what we have a white man's country, poverty is weakness and defeat' [my transl.]. ${ }^{51}$

Malan continued in this vein stating that in the context where the Afrikaner had to stand up for their volk, these representatives of the new Groot Trek met 'the nonwhite at his Blood River half- or even completely unarmed, without a hedge and without a river barrier, vulnerable on the open plain of economic equalisation' [my transl.]..$^{2}$

Despite this vulnerably, for Malan the Afrikaner's strength, even possible salvation, lay in its strong bias against racial mixing. Contrary to the Carnegie report's suggestion that the social dividing wall's slow yet steady disintegration might lead to increased interracial relationships, Malan asked whether 'you as Afrikaner should not thank God that the report could still add that "this is still an exception even among backward whites, and especially under those of the Afrikaans-speaking section?"' [my transl..]. ${ }^{53}$

When Malan moved to his conclusion he argued unambiguously that this idea of protecting racial purity was also a Voortrekker idea of primary concern, and that it had become much more urgent. 'As you have never before realised it, you realise today that their direction is your direction, that their path is your path, and that their task to make South Africa a white man's land, is your task, multiplied' [my transl... ${ }^{54}$

What is particularly significant about the commemoration of the centenary trek? Malan's hopes were both lofty and quasi-religious: This centenary year called the volk to awaken from their sleep of death.

49 'Knowledge is power. The terms of battle are changing, but at the expense of the whites' [my transl.] Ibid.

50 Ibid, 9 .

51 Ibid, 9.

52 Ibid, 10.

53 Ibid, 11.

54 Ibid, 12. 
Dis Danskraal en Bloedrivier wat dit weer oor Suid-Afrika se vlaktes uitbasuin dat om te kan oorwin jy bowe alles nodig het om op te kyk, en dat met die wederopstanding van die Afrikanerdom se ou idealisme daar ook uit die graf moet verrys nuwe hoop, nuwe vaderlandsliefde, nuwe wilskrag en nuwe eenheid..$^{55}$

Malan then asked his audience whether they had enough patriotism and inner power to ask on this God-given event that which was a case of life and death and more important than any other issue, i.e. 'the secured survival of your own white race? ${ }^{56}$

This, what might perhaps be termed a quasi-Hegelian Spirit-imbued history that was restricted to Afrikanerdom, this involvement of religious symbolism in connection with the volk, was interestingly the only theological theme discernible in this address by Malan. On one level one might possibly see a kind of social gospel influence playing a role here. We know that Malan was an evangelical of a peculiar kind, a modernist in the paradigm of Du Plessis. Yet this complete dissolution of theology within the category of volk seems really anomalous in terms of evangelicalism in its typical insistence on the transcendental. What one would more reasonably expect from a generic contemporary Afrikaner Reformed evangelical was perhaps something along the lines of Blood River as a miraculous act of God saving his people in the name of Christianity for the purpose of spreading that very Christianity. But in Malan's speech, Blood River seems to be a victory born out of the heroic action of Andries Pretorius and others. His understanding of God as illustrated here seems much more diffuse than one would have expected.

\section{BEYERS NAUDÉ'S GELOFTEDAG SERMONS}

Prior to concluding, I want to briefly refer to a different evangelical's understanding of Blood River and its commemoration roughly during this same period. This 'evangelical' ${ }^{57}$ is none other than the famous anti-apartheid activist, Beyers Naudé. Whatever he might have become later in his life, during this period he was most certainly an evangelical with mission interests.

His earliest Geloftedag sermon I am aware of was preached in 1940 in Wellington. ${ }^{58}$ Here he very much identified the Voortrekkers with the biblical Israel, in other words a volk elected by God. But elected for what? Called for the purpose

55 'It is Danskraal and Blood River that are proclaiming across the South African plains, that in order to be victorious you above all need to look upwards, and that with the resurrection of the Afrikanerdom's old idealism there must also rise up from the grave new hope, new patriotism, new willpower and new unity' [my transl.] Ibid,13.

56 Ibid, 14.

57 See Retief Muller, 'Evangelicalism and Racial Exclusivism in Afrikaner History: An ambiguous relationship,' Journal of Reformed Theology 7 (2013): 235-263.

58 See M. Coetzee, L. Hansen and R. Vosloo, Vreesloos Gehoorsaam: 'n Keur uit Beyers Naudé se Preke van 1939 tot 1997 (Stellenbosch: Sun Press, 2013), 25ff. 
of doing justice is the answer. Although the understanding of justice that Naudé had during this period was quite different from the way he understood it later, I find it significant that already in a 1940 he would use a Geloftedag sermon to emphasise this outward responsibility of the elected volk. Regarding his envisioned future, Naudé listed several obligations for the Afrikaner, including the following which clearly shows his position regarding the Afrikaner's relationship to other South Africans. They should be a "volk that regards it as a privilege to honour all its obligations towards "whites", "coloureds" and "natives" (voogdyskap) $)^{59}$ [my transl.]. This is not to suggest that everything in this sermon was about the Afrikaner's outward responsibility. Much of it concerned their well-known mythical past, regarding which he emphasised his volk's Holy history. ${ }^{60}$ In other words this is very much a typical sermon for Afrikaner Reformed Evangelicals during this period. Paternalistic, assured about the Afrikaner's role in God's plan for South Africa, but still very much maintaining a distinction between God and his people; in other words quite different from Malan's perspective above, and potentially allowing for the possibility that one's current self-understanding could be wrong and might have to be revised in future, as indeed happened in the case of Beyers Naudé over time.

\section{CONCLUSION: INTERROGATING COMMEMORATIONS}

This final reference to Beyers Naudé might seem out of place in an article that otherwise consistently points to ways in which memories of Voortrekkers had been used and abused to construct national identity among Afrikaners who were also committed to missionary work. I have, however, indicated with my reference to Huet for example, that such identity construction relied on rather simplistic binary narratives of the past, which could easily be deconstructed when thicker understandings of historical figures and their diverse interests and commitments emerge. However, this is precisely the problem with commemorations as such. The typical commemoration relies on a single story of victory against great odds, heroic martyrdom, etc. Commemorators are usually not interested in complex narratives; they do not make for strong punch lines.

What is the implication of this for more recent commemorations, then? I am particularly thinking of recent celebrations in which I participated commemorating the centenary anniversary of Beyers Naudé's birth. Of course one might argue that Naudé was clearly an exemplary figure. What could possibility be wrong with commemorating this man and his legacy?

59 Ibid, 30.

60 This theme disappears in later sermons preached on the occasion of Geloftedag when Beyers Naudé objects to the uncritical association of the Afrikaner nation with Israel. Ibid, 139. 
The answer is nothing of course, except that it is quite clear that in these earlier commemorations of the Ossewa trek, the celebrants were themselves convinced that the Great Trek was a morally exemplary cause. For them Blood River was a singular event. It denoted the birth of the Afrikaner nation, and with it the institution of South Africa as a 'white man's land'. It inaugurated the creation of an old New South Africa, if you will.

For many today, especially for progressive white Afrikaners, Beyers Naudé symbolises a new birth of sorts in history. He is a metaphor for a new way of being South African, a way which contradicts much of the ideas of that earlier generation of Malan et al. His struggle against that establishment out of which he had moved, was heroic at times. It might in any case easily be conceived and celebrated in such terms.

The reader might, therefore, with some justification feel that it is really absurd to compare commemoration of Beyers Naudé with commemoration of Voortrekkers. And of course it is. But the thing is that whenever you commemorate, you run the risk of freezing history in time and space. You run the risk of canonising and sacralising a specific narrative of the past. It might seem completely appropriate at the time, as it did for those abovementioned missionaries and pious Afrikaners who commemorated the Great Trek. The problem is that a frozen history might be used as a tool or even a weapon, but it hardly has any use for critically informing the present.

Instead, commemoration should rather coincide with historical interrogation of whatever is being commemorated. Then there is value to it, especially in terms of helping to contextualise the rapidly changing present.

\section{REFERENCES}

Brümmer, V. 'DF Malan en die Hoër Kritiek: Algemeen.' Nederduitse Gereformeerde Teologiese Tydskrif 54, no. 3\&4 (2013): 130-42.

Coetzee, M., Hansen, L. and Vosloo, R. (eds). Vreesloos Gehoorsaam: 'n Keur uit Beyers Naudé se Preke van 1939 tot 1997. Stellenbosch: Sun Press, 2013.

'Die Aanstaande Sending-konferensie.' In Die Kerkbode, 24 Augustus 1938.

'Die Sendingkonferensie.' In Die Kerkbode, 9 November, 1938.

Elphick, R. The equality of believers: Protestant missionaries and the racial politics of South Africa. Charlottesville [Va.]: University of Virginia Press, 2012.

Gedenkboek: Voortrekker Eeufees 1838-1938.

Gerdener, G.B.A. 'n Eeu van genade 1838-1938: Die sendingtaak van die Ned. Geref. Kerke van Suid-Afrika in oënskou geneem in die eeujaar van die Groot Trek. Kaapstad: S.A. Bybelvereniging, 1938.

Huet, D.P.M. Eéne kudde en één herder: verhandeling over de toebrenging van heidenen tot de christelijke kerkgameenschap. Kaapstad: Marais, 1860.

Kerkargief (Dutch Reformed Church Archives), Stellenbosch, South Africa. 
Kistner, W. 'The 16th of December in the context if Nationalistic thinking.' In Church and Nationalism in South Africa, Theo Sundermeier (ed.). Johannesburg: Ravan Press, 1975.

Louw, A.A. Sr. 'Vrug op ons Sendingwerk.' In 'n Eeu van Sendingwerk, 1938.

Malan, D.F. Die nuwe Groot Trek: Suid-Afrika se noodroep. Dr. D.F. Malan se Rede op Bloedrivier, 16 Desember 1938. DRC archive.

Müller, R. 'Evangelicalism and racial exclusivism in Afrikaner history: An ambiguous relationship.' Journal of Reformed Theology 7 (2013): 235-263.

Müller, R. 'War and "racial feeling" in the writings of an Afrikaner missionary.' Studia Historiae Ecclesiasticae, 40, 2 (2014): 71-84.

Nederduitse Gereformeerde Kerk and Sendingkonferensie. 'n Eeu van sendingwerk: Referate gelewer by geleentheid van die sendingkonferensie van die Gefedereerde Ned. Geref. Kerke in Suid-Afrika, Bloemfontein, 29 September - 3 Oktober 1938. Kaapstad: S.A. Bybelvereniging, 1938.

Retief, J.A. 'Op die wêreldhorison.' In'n Eeu van Sendingwerk, 1938.

Reyneke, J. 'Geestelike Eeufees Monument in Soeloeland.' Oorvloedige Lewe, Pretoria. DRC archive, Stellenbosch.

Ross, J.J. Die Sending te Witzieshoek, Paulus Mopeli, en andere sake rakende die sending aldaar. Bloemfontein: Nasionale Pers, 1930.

Ross, J.J. Vier Preken geleverd door eerw. J.J. Ross te Doornpoort, New Castle, Natal, met Dingaansfeest, 15-16 Des. 1917. Stellenbosch: Pro Ecclesia, 1918. DRC archive, B2139.

Snyman, D.R. 'Die Sendingkonferensie te Bloemfontein: 29 September tot 3 October.' In Die Kerkbode, 19 Oktober 1938.

Strydom, J.G. 'Die rassevraagstuk in Suid-Afrika.' In 'n Eeu van Sendingwerk, 1938.

Theunissen, M.W. Na die land van Dingaan. Stellenbosch: CSV Boekhandel, 1950.

Theunissen, M.W. '’n Roepstem uit die land van Dingaan.' In Die Kerkbode, 14 Desember 1938. 